\title{
APPROVAL OF CITICORP'S APPLICATION TO EXPAND DATA SERVICES ACTIVITIES: THE FEDERAL RESERVE BOARD'S POLICIES REGARDING NONBANKING ACTIVITIES
}

A recurring theme in modern banking is the tension between "federal regulatory statutes designed in part to limit bank activities, and attempts by banks-often sanctioned by federal banking authorities-to compete in broader lines of business." 1 The Citicorp ${ }^{2}$ order announced by the Federal Reserve Board on July 9, 1982 reflects this theme and presents insights into the Federal Reserve Board's standards and policies regarding bank holding company expansion into nonbanking activities. The order permits Citicorp, a bank holding company, to broaden its busmess by expanding its data services. ${ }^{3}$ The Board approved Citicorp's expanded services by relying on section 4(c)(8) of the Bank Holding Company Act, ${ }^{4}$ which allows the Board to approve nonbanking services "closely-related" to banking services. ${ }^{5}$

This note describes the flexible standards developed by the Board in applying the closely related exemption. These standards give the Board discretion to approve a wide range of nonbanking activities and challenge the longstanding policy that banking activities should remain separate from other commercial activities. ${ }^{6}$ Although the Board and

1. Investment Co. Inst. v. Board of Governors of the Fed. Reserve Sys., 606 F.2d 1004, 1010 (D.C. Cir. 1979), rev'd, 450 U.S. 46 (1981).

2. 68 Fed. Res. Bull. 505 (1982).

3. See id.

4. Bank Holding Company Act Amendinents of 1970, Pub. L. No. 91-607, \& 103(8), 84 Stat. 1760,1765 (amending section 4 of the Bank Holding Company Act of 1956) (codified at 12 U.S.C. \& 1848(c)(8) (1976)).

5. See Citicorp, 68 Fed. Res. Buil. at 505-06. See infra note 14 for the text of section 4(c)(8).

6. The policy of separation began when Congress concluded that the close association of commercial banking and securities activities contributed to the collapse of the nation's financial system in the early days of the Great Depression. See Board of Governors of the Fed. Reserve Sys. v. Investment Co. Inst, 450 U.S. 46, 61 (1981). Congress sought to effect a separation between national banks and securities activities through enactment of the Glass-Steagall Act. Id. at 62.

The Bank Holding Company Act of 1956 extended the policy of enforcing separation between banking and nonbanking activities to bank holding companies. See Pub. L. No. 511,70 Stat. 133. The restrictions of the Glass-Steagall Act were inadequate to deal with the special problems presented by bank holding companies, some of which controlled great networks of banks. SEN. REP. No. 1095, 84th Cong., 1st Sess. 2 (1955), reprinted in 1956 U.S. CODE CONG. \& AD. News 2482, 2483. In Congress' view, unrestricted growth of these financial conglomerates 
the courts have approved expansion of the activities in which banks can engage, ${ }^{7}$ an examination of the legislative history of section 4(c)(8) reveals that Congress did not clearly intend this result. ${ }^{8}$

This note examines the Board's interpretation of section 4(c)(8) and concludes that the interpretation may result in several harmful consequences.9 It does not, however, argue that reviewing courts should intervene to force the Board to apply inore rigorous standards; ${ }^{10}$ instead, Congress should review the standards and either approve or reject them. By reviewing the Board's standards, Congress can establish accountability and clear the uncertainty regarding the limits of bank holding company expansion into nonbanking activities. The note argues that, by inodifying the delegation doctrine, courts could encourage such congressional review. ${ }^{11}$

\section{The BoARD's Decision}

The Bank Holding Company Act prohibits bank holding companies from controlling coinpanies other than banks, ${ }^{12}$ with certain stated exeinptions. ${ }^{13}$ Citicorp filed its application under the section 4(c)(8) exemption, which sanctions nonbanking activities "closely related" to banking. ${ }^{14}$ Under section 4(c)(8), if the Board determines that a pro-

threatened to create dangerous concentrations of financial power. Id. The 1956 Act provided that bank holding companies could not control nonbank subsidiaries except under exemptions provided for by the statute. Bank Holding Company Act of 1956, supra, at 84,70 Stat. at 135-37 (codified as amended at 12 U.S.C. \& 1843 (1976)). One such exemption allowed nonbanking subsidiaries engaged in activities closely related to banking. Id. at $\& 4(c)(6), 70$ Stat. at 137 (codified as aniended at 12 U.S.C. $\& 1843(c)(8)$ (1976)).

The 1956 Act left a significant loophole in the scope of bank holding company regulation because it applied only to holding companies controlling two or more banks. See Bank Holding Company Act of 1956, supra, at \&2(a)(1), 70 Stat. at 133. The 1960s brought dramatic and unrestricted growth of one-bank holding companies not covered by the act, and this alarmed many observers. CONF. REP. No. 1747, 91st Cong., 2d Sess. 11-12, reprinted in 1970 U.S. CoDE CoNo. \& AD. News 5561, 5562. Congress extended regulation to one-bank holding companies by the 1970 Amendinents to the Bank Holding Company Act of 1956. See Pub. L. No. 607, \& 101(a), 84 Stat. 1760, 1760 (amending section 2(a)(1) of the Bank Holding Company Act of 1956) (codified as amended at 12 U.S.C. \& 1841 (a)(1) (1976)).

7. See infra Parts IA \& IB.

8. See infra Part IC.

9. See infra Part II.

10. See infra Part III.

11. See infra Part IV.

12. 12 U.S.C. \& 1843(a) (1976).

13. Id. \& 1843(c).

14. 68 Fed. Res. Bull. at 505.

Section $4(c)(8)$ provides thet holding companies may own shares of any company the activities of which the Board after due notice and opportunity for hearing has determined (by order or regulation) to be so closely related to banking or managing or controlling banks as to be a proper incident thereto. In determining whether a particular ativity is a proper incident to banking or managing or controlling banks the Board shall 
posed activity is closely related to banking and that approval will produce public benefits that outweigh possible adverse effects, it may approve the activity. ${ }^{15}$ Both tests must be satisfied: an activity that is not closely related to banking is not permitted even if great public benefits would accrue from approval.16

Citicorp applied to the Federal Reserve Board for permission to offer expanded data processing and data transmission services through

\footnotetext{
consider whether its performance by an affiliate of a holding company can reasonably be expected to produce benefits to the public, such as greater convenience, increased colnpetition, or gains in efficiency, that outweigh possible adverse effects, such as undue concentration of resources, decreased or unfair competition, conflicts of interests, or unsound banking practices. In orders and regulations under this subsection, the Board may differentiate between activities commenced de novo and activities commenced by the acquisition, in whole or in part, of a going concern.
}

12 U.S.C. $\& 1843$ (c)(8) (1976).

The "closely related" exception originated when Congress enacted the Bank Holding Coinpany Act of 1956. See Pub. L. No. 511, \& 4(c)(6), 70 Stat. 133, 137. The section was renumbered in 1966 as section 4(c)(8). See Act of July 1, 1966, Pub. L. No. 89-485, \& 8(c)(8), 80 Stat. 236, 239 (amending section 4 of the Bank Holding Company Act of 1956). The closely-related exemption was significantly revised in 1970. See Bank Holding Company Act Amendinents of 1970, Pub. L. No. 91-607, § 103(8), 84 Stat. 1760, 1765 (amending section 4 of the Bank Holding Coinpany Act of 1956) (codified at 12 U.S.C.8 1843(c)(8) (1976)). See infra Part IC for discussion of the significance of the changes enacted by the 1970 Amendinents.

15. National Courier Ass'n v. Board of Governors of the Fed. Reserve Sys., 516 F.2d 1229, 1232 (D.C. Cir. 1975). The court stated that "[t]here are two distinct issues raised by a bank holding company's seeking to hold shares in a company engaged in non-banking activities . . . . The first is whether those activities are "closely related to banking". . . The second or so-called 'public benefits' issue, [is] derived from the 1970 Amendinents to the act." Id. at 1232-33.

16. The question whether a one step or a two step test was intended under the amended section $4(c)(8)$ reflects the more basic disagreement over whether Congress intended the Amendments to broaden the scope of the exemption. See infra Part IC for discussion of the difference of opinion on this issue between the House and Senate Managers at the time the Amendinents were enacted.

Senator Sparkman, a proponent of the position that the exeinption was broadened, maintained that under the revised language, activities need only be related to banking generally in order to be a proper incident of banking. 116 CoNG. REC. 42,422, 42,424 (Amendinent of the Bank Holding Company Act of 1956-Conference Report to the Senate) (1970) thereinafter cited as Senate Managers' Report]. He viewed the newly added benefits test as defining the term "proper incident of banking," which indicates that he foresaw a meshing of the closely-related test



The majority of the House's representatives at the Conference Committee that drafted the final version of section $4(c)(8)$ envisioned a two step test. Their report states: "The effect of section $4(c)(8)$ as a whole is to establish, in effect, two tests for the Federal Reserve Board to use in deciding cases under section $4(\mathrm{c})(8)$. . . . Even if the activity is found by the Board to be closely related to banking, it must also determine whether it meets the public benefits test." CONF. REP. No. 1747, 91 st Cong., 2d Sess. 22, reprinted in 1970 U.S. CODE CoNG. \& AD. News 5561, 5572-73 (statement of the Managers on the part of the House) [hereinafter cited as House MANAGERs' REPORT].

The courts rejected attempts to mesh the tests, and the view of the House Managers has prevailed on this point. See, eg., Association of Bank Travel Bureaus, Inc. v. Board of Governors of the Fed. Reserve Sys., 568-F.2d 549, 551-52 (7th Cir. 1978) and supra note 15 for the view of the National Courier court. 
a subsidiary to be known as Citishare Corporation. ${ }^{17}$ The Board allowed Citishare to provide computer hardware and software designed to aid check collection, securities recordkeeping, and other financial functions; ${ }^{18}$ systems designed to facilitate interbank transfers of funds and transmit financial data; ${ }^{19}$ and computer terminals for home use that allow the customer to pay bills, receive financial information such as stock quotations, and perform budget and accounting functions in the hoine. ${ }^{20}$

\section{A. The Flexible Closely-Related Test Applied by the Board in Applications under Section 4(a)(8).}

The Citicorp order was based on the Board's interpretation of the closely-related test, which allows it a high degree of flexibility. The Board finds an activity "closely related to banking" if banks have historically provided the proposed service, banks generally provide services so operationally or functionally similar to the proposed services that they can easily provide the proposed service, or banks provide services so integrally related to the proposed service as to require their provision in a specialized form. ${ }^{21}$

The Board relied on each of these factors in approving the Citicorp application. For example, in approving the provision of timeshare data processing of financial, banking, and other economic

17. Cüticorp, 68 Fed. Res. Bull, at 505. The protestants were an association of data services companies and six independent data services companies. Id at $505 \& \mathrm{n} .1$.

After receiving Citicorp's application, the Board ruled that some of the proposed activities were not governed by previous regulations and ordered a formal hearing. Id at 505-06. The Act authorizes the Board to declare activities to be "closely related to banking" by regulation or by order. 12 U.S.C. 81843 (c)(8) (1976). A separate public benefits test must, however, be applied on a case-by-case basis before an application is approved. See infra text accompanying notes 52-53.

The Board lists activities that are closely related to banking in its Regulation Y. See 12 C.F.R. $\& 225.4$ (1982). At the time of the Citicorp order, Regulation $Y$ provided as follows:

The following activities have been determined by the Board to be so closely related to banking or managing or controlling banks as to be a proper incident thereto: . . . (8)(i) Providing bookkeeping or data processing services for the internal operations of the lolding company and its subsidiaries and (ii) storing and processing other banking, financial, or related economic data, such as performing payroll, accounts receivable or payable, or billing services.

Id. \$225.4(a). See infra notes 13-15 and accompanying text for the expanded range of data processing and transmission activities approved in the Cittcorp order.

18. Citicorp, 68 Fed. Res. Bull, at 508-09.

19. Id at 509 .

20. Id at 509-10. The protestants challenged four other proposed activities: processing financial and economic data through timesharing, providing hardware and software systems for authentication of identifiers for electronic transmissions, selling excess capacity for any purpose, and selling by-products of approved activities. Id. at 507-08, 510-11. The Board approved each of these activities.

21. Id. at 506. Only one factor need be present for the activity to meet the test. 
data, the Board noted that banks currently utilize data processing services in performing their own credit functions and in performing financial bookkeeping and accounting operations for other businesses. 22 Because banks already provide the service, the activity falls within the first part of the three factor test. This determination was objective: the Board based its decision on the current activities of bank holding companies.

In contrast, the Board approved Citicorp's proposal to provide software to banks and other financial institutions for check collection, recordkeeping, and other financial activities because it found the proposal functionally similar to the correspondent services that banking organizations already offer. ${ }^{23}$ This determination was subjective: the Board found that offering software to perform financial functions is similar to the performance of such functions by a correspondent bank. The third factor of the test, which requires that the proposed activities be integrally related to banking activities, allows the Board similar flexibility in evaluating closely relatedness. ${ }^{24}$ The second and third factors do little either to set a certain standard for the application of section $4(c)(8)$ or to limit the Board's discretion.

The Board's practice of approving some activities concededly unrelated to banking by characterizing them as necessary incidental activities expands its discretion. For example, although the provision of computer hardware did not coinply with the three factor test because providing hardware is unrelated to banking, the Board approved it.25 The Board characterized the activity as incidental to an activity that is

22. Id at 507 .

23. Id. at 508 .

24. The Board used the third factor in approving electronic fund transfers activities. See id. at 509. The Board found that the need for security and accuracy required that these services be allowed in a specialized form. Id.

25. Citicorp, 68 Fed. Res. Bull. at 509. Why the Board found the provision of software to fall within the three factor test of relatedness but refused to approve the provision of hardware on the same grounds is difficult to determine. The Board found the provision of software to be functionally similar to services generally provided by banks; it therefore satisfied the second factor of the test. See supra text accompanying note 23. Further, the Board noted that hardware and software are normally developed as an integrated package. Citicorp, 68 Fed. Res. Bull. at 508 . The activities appear to be equally related (or unrelated) to banking.

A possible explanation for this straired reasoning is that the Board did not want to rely excessively on the incidental activity rationale in approving the proposed services. Section $4(c)(8)$ does not provide for an incidental activities exception; it states simply that activities must be closely related to banking. See supra note 14. The incidental activities rationale is a creation of the Board, approved in limited circumstances by a reviewing court. See National Courier, 516 F.2d 1229, 1240-41. The National Courier court did not establish the limits to which the rationale may be pushed, but struck down an atteinpt by the Board to employ it to approve an activity that was not reasonably necessary to allow holding companies to engage in other activities found to be closely related to banking. See id at 1241. 
closely related to banking. ${ }^{26}$ Thus, the apphication of the test followed by the Board in the Citicorp order results in approval of activities either largely unrelated to banking or related only in the sense of a perceived functional similarity. ${ }^{27}$

\section{B. The Reaction of Reviewing Courts to the Board's Standards in Applying Section 4(c)(8).}

In past decisions reviewing the Board's application of the exemption, courts have generally accepted the Board's expansive apphication of section $4(\mathrm{c})(8)$. The Board takes its three factor test for evaluating closely relatedness froin the decision of the Court of Appeals for the District of Columbia in National Courier Association v. Board of Governors of the Federal Reserve System. ${ }^{28}$ The National Courier decision also supports the Board's practice of approving activities unrelated to banking as permissible incidental activities under certain conditions. ${ }^{29}$ Even the liberal National Courier court ${ }^{30}$ noted that if the Board is permitted to string together an unending chain of functional and inciden-

26. Citicorp, 68 Fed. Res. Bull. at 509. The Board allowed provision of hardware only so long as the cost of hardware does not regularly exceed 30 percent of the total charge for data services. Id

27. See supra note 25 for a discussion of approval of unrelated activities in the Citicorp order. The approval of Citicorp's application to offer homebanking services provides a good example of the Board's flexibility in applying the closely-related test. Approval includes authority to offer cash management, financial information and home accounting functions. Citicorp, 68 Fed. Res. Bull. at 510. The Board approved these activities because it believed that they were functionally similar to other services offered by banks. Id. The provision of computer hardware and software necessary to offer these services was approved under a strained combination of the incidental activities rationale and the functionally similar factor of the three part test. See supra note 25.

The Board's formulation of standards under section $4(c)(8)$ is flexible cnough to allow approval of these activities despite the fact that banks have not offered these services in the past, and large portions of the cost of offering the services represent the cost of provision of hardware and software systems.

28. 516 F.2d 1229 (D.C. Cir. 1975); see Citicorp, 68 Fed. Res. Bull. at 506.

29. See supra note 25 .

30. The National Couvier court interpreted section $4(c)(8)$ liberally in concluding that Congress intended to expand the scopo of permissible nonbanking activities substantially when it enacted the 1970 Amendinents. See 516 F.2d at 1236. In Alabama Ass'n of Ins. Agents v. Board of Governors of the Fed. Reserve Sys, the Fifth Circuit Court of Appeals adopted a conservative interpretation of the provision, concluding that the Amendments did not significantly change the range of the Board's discretion to approve nonbanking activities. See 533 F.2d 224, 239 (5th Cir. 1976), modiffed, 558 F.2d 729 (1977), cert. denied, 435 U.S. 904 (1978).

The Alabama Ass'n court concluded that in enacting the 1970 amendinents, Congress intended to ratify the standards applied under the closely-related exemption of the Bank Holding Company Act of 1956. See id. Nevertheless, the court approved the three factor test establislred by the National Courier court. Id. at 241. The court reasoned that its review of the Board's application of the statute should not be overly restrictive because the Board's standards under the pre-1970 exemption provision were not particularly restrictive. Id. at 239-41. The court's conclusion that the pre-1970 standards were not restrictive is not supported by analysis of pre-1970 
tal relationships, the limitations of section $4(c)(8)$ will become meaningless. ${ }^{31}$ The court therefore held that the Board may not tack one close relationship onto another indefinitely. ${ }^{32}$

The National Courier court established a test to evaluate whether chaining of close relationships is permissible. The court defined "horizontal chaining" as provision of financial services similar to those traditionally offered by banks, and "vertical chaining" as provision of services that are not related to banking per se, but allow banks to expand the scope of the banking-related services that they offer. ${ }^{33}$ The court allowed vertical chaining only when necessary to facilitate horizontal chaining. When vertical chaining accomplished no horizontal expansion, it was struck down. ${ }^{34}$

The Board approved combinations of horizontal and vertical chaining in the Citicorp order. A good example is the approval of homebanking services. ${ }^{35}$ Homebanking can be broken down into two activities: (1) provision of information and financial services; and (2) provision of computer systems. The information and financial services represent horizontal chaining because the Board found them to be closely related to banking under the three factor test. ${ }^{36}$ The provision of computer systems is vertical chaining because it is unrelated to banking and was approved only as an imcidental activity. ${ }^{37}$ Since the

Board orders applying the exemption. The Board actually applied standards significantly more rigorous than those applied under the three factor test. See infra note 52.

The point, however, may have been rendered moot because the Supreme Court appears to have accepted indirectly the liberal interpretation of the National Courier court. Although the Supreme Court noted the existence of competing interpretations of the statute, it refused to explicitly approve either. See Board of Governors of the Fed. Reserve Sys. v. Investunent Co. Inst., 450 U.S. 46, 73-74 (1981). Instead, the Court stated that the greatest deference is to be given to the Board's application of section $4(c)(8)$. Id at 56. This standard of review appears to ratify the Board's interpretation of the statute, which parallels the liberal interpretation given by the $\mathrm{Na}$ tional Courier court. See infra text accompanying notes 82-86.

31. National Courier, 516 F.2d at 1239. See infra note 34 for discussion of the court's review of the Board's approval of courier services in the National Courier case.

32. National Courier, 516 F.2d at 1239.

33. Id

34. Id In National Courier, the court upleld in part and rejected in part the Board's approval of the provision of courier services by banks. Id. at 1232. The court upleld approval of courier services in circumstances where, by offering courier services, banks could expand their financial data processing activities. Id at 1239 . The financial data processing activities represented horizontal expansion because they are closely related to banking per se and the courier services represent vertical draining, because they are related to banking only in that they allow expansion of activities closely related to banking. Id. The court refused to approve courier services when they were not necessary to facilitate the expansion of activities closely related to banking. Id at 123941.
35. See supra note 27.
36. See supra note 27.
37. See supra note 25 and accompanying text. 
Board's approval of the provision of computer systems only makes possible the expansion of banking related activities, the approval does not appear open to attack under the rule of National Courier, even though the Board applied different portions of the three factor test as well as the incidental activity justification in tandem.

National Courier allows the Board broad, flexible powers in interpreting section 4(c)(8), and the Citicorp order demonstrates that the Board will not hesitate to use those powers. In order to judge whether the flexible approacls is consistent with the intent of Congress in passing section $4(c)(8)$, the statute's legislative history inust be analyzed.

\section{The Legislative History of the 1970 Amendments.}

Congress amended section $4(c)(8)$ in 1970.38 The legislative history of the amendments reveals a deep division of opinion among the legislators regarding the significance of the revisions to section 4(c)(8). ${ }^{39}$ The bills that emerged from both Houses contained language considerably different from the final version adopted by the Conference Committce, which Congress enacted into law. Both the Senate and House versions substituted a "functionally related" test for the closely-related standard of the 1956 Act, but the House included a list

38. Bank Holding Company Act Amendments of 1970, Pub. L. No. 91-607, $\$ 103(8), 84$ StaL. 1760,1765 (codified at 12 U.S.C. 81843 (c)(8) (1976)).

39. Commentators discussed the division soon after enactment of the Amendments. See Chase, The Emerging Financial Conglomerate: Liberalization of the Bank Holding Company Act, 60 GEO. L.J. 1225, 1238-39 (1972); Note, The Bank Holding Company Aet Amendments of 1970, 39 GEO. WASH. L. REv. 1200, 1217-23 (1971); Comment, Implementation of the Bank Holding Company Act Amendments of 1970: The Scope of Banking Activities, 71 MrCr. L. REv. 1170 (1973).

The 1970 Amendments did not effect a great change of language from the original closelyrelated exemption enacted as part of the Bank Holding Company Act of 1956. See supra note 14 for a discussion of the history of the closely-related exemption.

The changes effected by the 1970 Amendments include the elimination of the introductory clause referring to "financial, fiduciary or insurance" activities. This change was not intended to effect a substantive change in the test but to eliminate redundant language. House MANAOERs' RePORT, supro note 16, at 14-15, 1970 U.S. CoDe CoNa. \& AD. News at 5565-66.

The effect of the elimination of the reference to the "business of banking" was relied on by the Senate Managers to the Conference Committce who argued that the Amendments were intended to broaden and liberalize the closely-related exemption. Senator Sparkman stated that even if the closely-related language was retained, liberalization of the provision would be achieved by eliminating the "business of banking" language. SENATE MANAGERs' REPORT, supra note 16 , at 42,424 .

The 1970 House Managers' Report, lowever, states that this change was intended only to make clear that a proposed activity need not relate "to the specific business carried on by the subsidiary banks of the particular loolding company involved.' " House MANAaERs' RePORT, supra note 16, at 16, 1970 U.S. Code CoNG. \& AD. News at 5567. Under the House view, the substance of the 1956 closely-related test was to remain intact. Id. at 21, 1970 U.S. CODE CONG. à Au. iNews at 5572. 
of prohibited activities as well.40 The Conference Committee had great difficulty reaching a compromise between the House and Senate bills. ${ }^{41}$ The Senate Conferees refused to accept the restrictive list of prohibited activities contained in the House bill. ${ }^{42}$ The Committee settled the issue by striking the list of prohibited activities and reinserting the old "closely related" language for the new "functionally related" language. ${ }^{43}$ After the Conference Committee adjourned, the House and Senate Managers issued reports clearly demonstrating that dramatic differences in the views of the legislators remained even as the revised version of section $4(\mathrm{c})(8)$ was enacted.

The Senate Managers' Report states that Congress intended the Amendments to free the Board from restrictive precedents established under the old act.44 Senator Bennett stated that the Committee's version of section 4(c)(8) maintains the maximum flexibility for the Federal Reserve Board called for by the Senate's original bill.45 At the other extreme, the House Managers' Report states that the Conference Committee rejected attempts to liberalize the closely-related exemption and agreed to inaintain the closely-related test of the 1956 Act. 46 As one commentator stated, evaluating this legislative history requires "an

40. See SeN. REP. No. 1084, 91st Cong., 2d Sess. 12 (1970), reprinted in 1970 U.S. CODE Cong. \& AD. News 5519, 5530; H.R. Rep. No. 387, 91 st Cong., 1st. Sess. 9 (1969).

41. House Managers' Report, supra note 16, at 13, 1970 U.S. CODE Cong. \& AD. News at 5564 .

42. See id. at 13, 1970 U.S. CODE Cong. \& AD. NEwS at 5564.

43. See id. at 13-14, 1970 U.S. Code CONG. \& AD. News at 5564.

44. SenAte Managers' Report, supta note 16, at 42,424 .

45. Id at 42,432 (statement of Senator Bennett). Senator Bennett added that he considered the House interpretation of the bill to misconstrue the Conference Committee's decision. Id. In approving the original Senate bill, the Senate Committee supported substitution of a new functionally related test as a means of increasing the Board's flexibility in dealing with applications to offer nonbank services. SEN. REP. No. 1084, 91st Cong., 2d Sess. 12-15, reprinted in 1970 U.S. CODE CONG. \& AD. NEwS 5519, 5530-33. Under this more flexible approach, the Senators foresaw Board approval of a wide range of nonbank activities such as acting as travel agents, leasing equipment, and providing data services. Id. at 13, 1970 U.S. CODE CONG. \& AD. NEWS at 5532. The Senate viewed flexibility as desirable because it would allow approval of activities necessary for banks to compete effectively and maintain their profltability in the face of emerging changes in the financial industry. Id. at 13-14, 1970 U.S. CODE CONG. \& AD. NEwS at 5532.

46. House MaNagers' Report, supra note 16, at 21, 1970 U.S. CODE CONG. \& AD. News at 5572. Therefore, the House Managers intended to ratify the standards used by the Board in applying the exemption prinr to the 1970 Amendments. Their report states that expansion or liberalization of the provision was not justified. Id at 21, 1970 U.S. CODE CONG. \& AD. NEwS at 5572.

Under the Bank Holding Company Act of 1956, the Board construed the closely related provision to permit only those nonbanking activities that were so intimately tied with banking operations as to be a reasonably required part of the banking business. Transamerica Corp., 43 Fed. Res. Bull. 1014, 1029 (1957). The Board required more than a showing of common traits, which appears to be sufficient under current standards. See supra note 27 for discussion of the approval of homebanking activities based on similarities to activities engaged in by banks and the inciden- 
almost 'intuitive' assessment of motives and intentions." 47 In any case, the House Managers' Report demonstrates that solne members of Congress did not intend to liberalize the closely-related test of the 1956 Act. ${ }^{48}$

\section{The Public Benefits Test}

\section{As the Citicorp order demonstrates, the Federal Reserve Board has chosen to adopt the liberal view of the Senate Managers. ${ }^{49}$ The Board's}

tal activities rationale. Under the Transamerica order, relatedness demonstrated by kindred characteristics was not controlling. 43 Fed. Res. Bull, at 1029.

Otto Bremer Co., 46 Fed. Res. Bull. 621 (1960), provides an example of the Board's preamendment test. The Board approved retention of an insurance subsidiary, but only after noting that the insurance activities had been carried on by the small local bank for over fifty years. Id. at 622. Further, all insurance activities were conducted by bank employees who had banking duties, the insurance was sold only in the bank's building, and 99 percent of all sales were made to bank customers. Id. at 622-23. The Board emphasized the necessity of the traditional connection of the insurance activities to the bank's operations and the intermingling of banking and insurance activities. Id at 623 .

The Board continued to require these stringent indicia of relatedness throughout the pre-1970 Amendment period. In Senate Hearings before adoption of the Amendinents, Arthur Burns stated:

Virtually all of the subsidiaries established nnder section $4(c)(8)$ have been insurance companies or agencies. Where an insurance agency is involved, the Board has interpreted the provision as requiring a 'direct and significant connection' between the activities of the agency and those of subsidiary banks. The connection may be established, for example, by the fact that the insurance agency will be housed in bank offices and use bank personnel, or that its income will be derived from bank related transactions or insurance sold to bank customers.

Hearings on S.1052, S.1211, S.1064, S.3823 and H.R.6778: Before the Senate Committee on Banking and the Currency, 91 st Cong., 2d Sess. 141 (1970)(statement of Arthur Burns). Burns' language parallels that used by the House Managers, who stated that section 4(c)(8) applies only if there is a direct and significant connection between the proposed activities and the current activities of banks. House MaNAGERs' Report, supra note 16, at 21, 1970 U.S. CODE CONG. \& AD. News at 5572.

47. Note, supra note 39, at 1223. For instance, Representative Widnall argued against the position of the House Managers and noted that only four of the seven House Conferees signed the restrictive House Managers' Report that denied the Board additional flexibility under the exemption provision. 116 CoNo. REC. 41,949, 41,954 (conference report on H.R. 6778, Bank Holding Company Act Amendinents) (1970).

In addition, Senator Proxmire, a Senate Conferce, rejected the biberal position of the Senate Managers, stating that the Conference Committee agreed essentially to retain the standards existing under the 1956 Act. SenATE MANAGERs' Report, supra note 16, 116 CoNG. REC. at 42,427. He argued that heralization of the provision was not justified. Id. at 42,428.

48. In Association of Bank Travel Bureaus, Inc. v. Bocrs of Governors of the Fed Reserve Sys, the petitioner argued against the court's reliance on the House Managers' Conference Report because it was signed by only four of the twelve members of the Conference Committee. See 568 F.2d 549, 552 \& n.4 (7th Cir. 1978). The court rejected this argument, noting that under the rules then in effect, only the House Conferees had the right to prepare the report, and the four signatures constituted a majority of a possible seven House members entitled to sign the report. Id.

49. In approving homebanking activities, the Board relied on fnnctional similarities between the proposed activities and activities currently engaged in by banks. See supra note 27 . The 
action may not present difficulties, however, because section $4(\mathrm{c})(8)$ provides a second test, the public benefits test, which the Board must apply. ${ }^{50}$ The Senators justified expansion of the scope of the exemption, in part, by noting that the addition of the public benefits test would help to guard against adverse effects. ${ }^{51}$ In theory, apphication of the two part test should result in approval of only those activities that provide net benefit to the public. If so, liberalization of the exemption provision does not pose great danger to the public. This justification for liberalization is acceptable only if the public benefits test can be applied accurately. The analysis that follows demonstrates that the public benefits test can not be applied with any high degree of accuracy.

\section{A. The Board's Decision Under the Public Benefits Test.}

The Board may declare an activity to be closely related to banking by regulation, ${ }^{52}$ but the public benefits test requires the Board to scrutinize each application for potential benefits or detriments to the public before it allows a holding company to engage im a nonbank activity. ${ }^{53}$ Although the statute clearly specifies potential benefits and adverse fac-

functional similarities approach reflects the views of the Senators who wished to broaden the exemption by granting the Board increased flexibility. See supra note 45.

The House Managers explicitly rejected the functionally related approach to applying the exemption. House MANagers' REPORT, supra note 16, at 21, 1970 U.S. CODE CONG. \& AD. NEwS at 5572 . See rupra note 46 for discussion of the more stringent standards envisioned by the House Managers.

50. The dangers that section $4(c)(8)$ was intended to guard against include the potential for unfair competition and concentrations in our economy. See infra Part II for discussion of the risk of the anticompetitive practice of tying and supra note 6 for discussion of the policy of separating banking and commercial activities to prevent undue concentrations of economic power.

51. The Senate Report notes testimony that inclusion of the public benefits test will help guard against risks to competition resulting from liberalization of the closely related test. SEN. REP. No. 1084, 91st Cong., 2d Sess. 14, reprinted in 1970 U.S. CODE CONG. \& AD. News 5519, 5532.

52. 12 U.S.C. \& 1843(c)(8) (1976). Allowing determination of closely-relatedness by regulation is sensible because the factors considered in reaching the conclusion under this test are of industry-wide scope. See Independent Bankers Ass'n v. Board of Governors of the Fed. Reserve Sys., 516 F.2d 1206, 1215 \& n.29 (D.C. Cir. 1975). Under the three factor test for closely-relatedness, evidence is considered that demonstrates that banks generally provide the service, that the service is functionally related to services generally offered by banks, and that the service is integrally related to services offered by banks generally. See supra note 21 and accompanying text. This evidence is drawn from the banking system as a whole and not from fact situations particular to any individual holding coinpany. Such broad based factual determinations are determinations of legislative facts and are properly determined by rules with a broad prospective application. Id. at 1212 nn.26\& 29.

53. Id. at 1216. Under the benefits test, the Board must find that the performance of the proposed activity can be expected to produce public benefits, such as convenience, efficiency, and increased competition, that outweigh adverse factors such as undue concentrations of resources, unfair competition, or unsound banking practices. 12 U.S.C. $\$ 1843$ (c)(8) (1976). These are issues 
tors to be considered by the Board, ${ }^{54}$ the test is difficult to apply because the Board often lacks information necessary to make an accurate decision. The Board must predict what effects approval will have in a complex economic setting. An illustration is the Board's analysis of the potential adverse effects of voluntary tying arising from approval of Citicorp's application.ss

Voluntary tying occurs when a customer believes that he can more easily obtain a scarce product (such as bank credit) if he voluntarily accepts other products (such as the bank's data services) from the same seller, rather than seeking these products in the market.s6 In the context of banking, voluntary tying occurs because bank customers have great incentives to remain in the good graces of their banker. 57 When credit is tight, banks have the power to allocate funds, and ${ }^{58}$ because there is limited coinpetition in the industry, banks may allocate credit to the best customer, not to the highest bidder.59 Customers may seek best-customer status by buying other bank services, which leads directly to the voluntary tying problem. ${ }^{60}$

Voluntary tying is, as the Board notes, a structural problem based on the nature of competition in banking markets. ${ }^{61}$ Because government regulation creates the necessary climate for voluntary tying, and because regulated firms can reap benefits from it at the expense of competitive firms, the government should attempt to find equitable solutions respecting the imterests of consumers and nonbank businesses before allowing bank holding companies to expand into new markets. ${ }^{62}$ The Board in Citicorp concluded that the competitive market for commercial loans will preclude voluntary tying. ${ }^{63}$ The Board reasoned that a consumer would feel no compulsion to buy a bank's data services in

of adjudicative fact that depend on the particular characteristics and situation of the applicant, and may not be determined by regulation. Independent Bankers Ass'n, 516 F.2d at 1216 .

54. See supre note 53.

55. Tying is an adverse effect on competition that Congress believed should be considered in applying the benefits test. See SEN. REP. No. 1084, 91st Cong., 2d Sess. 16-17, reprinted in 1970 U.S. CODE CONG. \& AD. News 5519, 5535.

56. Caticorp, 68 Fed. Res. Bull. at 511.

57. See Competition in the Computer and Data Proeessing Industry and Its Effect on Small Business: Hearings Before the Subcommittee on Antitrust and Restraint of Trade Activities Affecting Small Business of the House Commitree on Small Business, 97th Cong., 1st Sess. 21 (1981) (statement of Albert Foer, Federal Trade Commission) [hereinafter cited as 1981 House Hearings.]

58. Id

59. Id

60. See id.

61. Cüticorp, $68 \mathrm{Fed}$. Res. Bull. at 511.

62. See 1981 House Hearings, supra note 57, at 21 (stutement of Albert Foer, Federal Trade Commission).

63. Cuticorp, $68 \mathrm{Fed}$. Res. Bull. at 512 . 
order to obtain credit or other bank services. The customer could simply obtam credit from a competitor not offering data services. ${ }^{64}$

The Board's analysis is incomplete; tying could become a great problem if all banks begin to offer data services. Banks tend to follow an innovative leader's entry into new fields of activity. ${ }^{65}$ Assuming that the Board does not intend to give Citicorp exclusive rights to offer expanded data services, such services will probably be offered by many banks in the future. The Board's argument that coinpetition will prevent voluntary tying is invalid if this occurs.

The Board notes in Citicorp that it is not required to insure against every hypothetical adverse contingency connected with a proposal.66 Admittedly, the increased risk of voluntary tying that would attend large-scale entry by banks into newly authorized activities is hypothetical, but the risk is nonetheless significant. ${ }^{67}$ The protesters depend on

64. Id.

65. For example, approximately 25 banks were using or testing home banking systems by the end of 1982. Padilla, Home-Banking Tests Begin in a Few Places, but the New Systems May Be Slow to Spread, Wall St. J., Jan. 17, 1983, at 25, col. 4.

66. Citicorp, 68 Fed. Res. Bull. at 511.

67. The failure to account for the risk of tying also produced mistakes in other parts of the Board's reasoning. For instance, the Board noted that a significant benefit of Citicorp's entry into new areas in the data services industry is that the entry would be de novo. Citicorp, 68 Fed. Res. Bull. at 513. The statute allows the Board to favor de novo entry. See 12 U.S.C. \& 1843(c)(8) (1976). In the Citicorp order, the Board states that it presumes de novo entry to be procompetitive in the absense of evidence to the contrary. 68 Fed. Res. Bull. at 513 . The anticompetitive effect of tying represents a real risk to the competitive conditions in the data services industry. By failing to accept this risk, the Board fails to consider evidence contrary to its presumption that pro-competitive benefits will flow from de novo entry.

The risk of allowing banks to enter the data processing market is significant. Generally, entry of regulated firms into a competitive industry presents a risk of suppression of competition and eventual dominance by the regulated firms. See 1981 House Hearings, supra note 57, at 18 (statement of Albert Foer, Federal Trade Commissiou). These risks accrue because regulated firms have special advantages over unregulated firms, such as protection from competition in their regulated markets, government-granted economic power over vital products (such as credit), and government control of their pricing inechanisms (such as regulation of interest rates paid on deposits). See id. at 19.

Independent data services companies argued that allowing regulated bank holding companies to enter the data services industry would result in the banks' eventual domination of the industry. See id at 50-51 (testimony of John Reardon). These companies were concerned with the potential for tying; banks are able to offer their banking services along with data processing services, yet barriers to entry into the banking industry prevent the data service companies from offering this conbination. See id. at 52-54 (testimony of Mr. Reardon and Mr. Chaffin). This advantage allows holding companies to take the business of independent data service companies not because of superior price, quality, or delivery, but rather, because their customers need credit and think that buying data services from a bank may help them get it. Id. at 3 (testimony of Mr. Chaffin).

Study of conditions existing in industries that have been open for bank holding company entry for some time indicates that the fear of independent processors is not baseless. The mortgage banking and consumer finance industries have been particularly attractive targets for holding company entry, and bank holding companies have already become powerful, if not dominant in 
access to the market place for their survival. Should a significant portion of the financial, business, and home computer markets become tied to other bank services, the independent companies would be jeopardized. Yet the Board failed to consider this risk because the line of inquiry required is speculative. ${ }^{68}$

The problem is exacerbated because competitors often have no way to correct the Board's errors im judgment. Nonbank competitors are often unable to use antitrust remedies until they have been severely damaged, ${ }^{69}$ and in the case of voluntary tying, antitrust remedies are not available at all.

[T] the tying is truly voluntary, with no coercion on the part of the regulated entity, there is no antitrust violation. Likewise, there is no conduct for regulators to monitor, making traditional regulatory scrutiny an ineffective response. . . . Nor is it sufficient to respond that regulators need not worry so long as consumers are merely making voluntary choices in the marketplace. Although the antitrust laws may not be violated by voluntary tying, the consequences may be just as harmful to competitors and consumers as unlawful coercive tying - competitiors are foreclosed from part of a market for reasons unrelated to the competitive merits of their product.70

In justifying its decision in Citicorp, the Board noted that the data processing services industry presently has a large number of firms and low barriers to entry. ${ }^{71}$ Admittedly, not every case of bank holding company expansion imto nonbanking activities threatens competition. In some cases, banks are responding to invasious of their own industry by strong institutions from other regulated industries ${ }^{72}$. Reducing the

both of these industries. Rhoades, Aggregate Concentration: An Emerging Issue in Bank Merger Policy, 24 Antrtrust BunL. 1, 10-11 (1979).

68. Similar problems are inherent in agency attempts to resolve issues involving complex predictions of future effects in adjudicatory proceedings.

[S]ince the adjudicator is purporting to decide only the case before him, he may be less concerned with the long-run consequences of the decision or of a series of decisions. The focus on "justice in the individual case" does not lend itself to intelligent forward planning, to rational consideration of major options and alternatives, and to a concern for the aggregate effects of individualized decisions.

Cramton, A Comment On Trial-Type Hearings in Nuclear Power Plant Siting, 58 VA. L. Rev. 585, 590 (1972).

69. 1981 House Hearings, supra note 57, at 107 (testimony of A. Biddie).

70. Id. at 21 (testimony of Albert Foer, Federal Trade Commission). See generally P. AREEDA, ANTTrRUst ANALYSIS 541 (1981).

The Board provides no significant protections against voluntary tying. The Board simply notes that data services will be marketed under the name "Citishare" instead of "Citicorp" and that no proof of tying activities engaged in by Citicorp in the past was presented. Citicorp, 68 Fed. Res. Bull. at 512 .

71. Citicorp, 68 Fed. Res. Bull at 512 .

72. "Less regulated institutions have inoved promptly to provide new services, often in direct competition with traditional depository institutions. Every week brings new competitors to this natioual financial marketplace." LaFalce, Banking in the Eighties, 37 Bus. LAw. 839, 839 (1982). 
restrictions on nonbanking activities in these cases allows banks to respond to such challenges. ${ }^{73}$

This suggests that factors beyond those called for under either the closely-related test or the public benefits test should be considered. If the industry to be entered by bank holding companies is a regulated industry, the presumption that de novo entry is pro-competitive may be justified. ${ }^{74}$ Entry in these cases may be warranted, especially if institutions in the nonbanking industry to be entered are making significant inroads into the banking industry. The Citicorp order, however, permits entry into competitive industries whose members cannot enter the banking field. They cannot hope to enjoy the benefits of tying their services to banking services that may naturally accrue to bank holding companies.

Allowing entry in this case, when the regulated competitors could dominate the market, demonstrates the probleins of applying a meaningful benefits test. Because the Board disfavors speculation, sucli risks as voluntary tying, are not factored into the benefits equation, and are not adequately protected against. ${ }^{75}$ Even if the Board adopts a policy of considering such risks, section 4(c)(8) does not say how much weight should be given to any particular benefit or adverse factor. The test leaves the Board great discretion and fails to guarantee that approval of an activity will produce net public benefits. In light of these problems, the Board's hiberalization of the closely-related test presents dangers, and the Board lias made its decision to adopt a liberal standard without a clear mandate from Congress. ${ }^{76}$ How, then, should a reviewing court react when faced with a challenge to a Board order approving an application under section 4(c)(8) based on the Board's flexible standard?

\section{The Limited Role of the Courts in Setting Standards fOR Application of the Closely-Related Test.}

By statute, the Federal Reserve Board's findings of fact are subject to judicial review under the substantial evidence standard. ${ }^{77}$ Under

73. "If nondepository institutions are to be allowed to compete with banks in functions long associated with depository institutions, then, many argue, certain depository institutions should be permitted to compete in areas long associated with the securities industry." Id. at 846.

74. See supra note 67.

75. Developing methods to guard against voluntary tying is difficult, and no certain solution to the problein exists. See 1981 House Hearings, supra note 57, at 21 (statement of Albert Foer, Federal Trade Commission).

76. See supra text accoinpanying notes $46-48$.

77. Courts must uphold the Board's findings of fact if the findings are supported by substantial evideuce. 12 U.S.C. $\$ 1848$ (1976). The substantial evidence standard for review of Board orders is identical to the standard provided by the Administrative Procedure Act, 5 U.S.C. 
this standard, the court will consider only supporting evidence explicitly noted by the Board, ${ }^{78}$ but if the Board notes evidence that a reasonable person might accept as adequate to support the Board's conclusions, the court must uphold the Board's findings. ${ }^{79}$ The court may not reverse, even if its own conclusion is "diametrically opposite". ${ }^{80}$

Despite the deference accorded agency findings of fact, the Board's flexibility in applying the closely related test conld be substantially restricted if the court interpreted section 4(c)(8) narrowly. The court has this power because the proper definition of the statutory phrase "closely-related" is a question of law, not fact.81 Although the court can reverse the Board's interpretation of the statute, whether it should use this power or defer to the Board's interpretation requires careful consideration.

The Supreme Court elected the course of deference in Board of Governors of Federal Reserve System v. Investment Co. Institute and refused to establish an authoritative interpretation of section $4(\mathrm{c})(8) .{ }^{82}$ The Court approved the Board's hiberal interpretation indirectly, stating that courts must give the Board's interpretation of the closely-re-

8706 (2)(E) (1976), for review of formal agency adjudications. Independent Bankers Ass'n, 516 F.2d at 1217 .

78. Mercantile Tex. Corp. v. Board of Governors of Fed. Reserve Sys., 638 F.2d 1255, 1260 (5th Cir. 1981).

79. Board of Governors of Fed. Reserve Sys. v. First Lincolnwood Corp., 439 U.S. 234, 253 (1978). As a practical guide, the Board's findings of fact appear to be most vulnerable when they diverge from the fiatings made by the administrative law judge. Cf. Florida Ass'n of Ins. Agents v. Board of Governors of Fed. Reserve Sys., 591 F.2d 334, 340 (5th Cir. 1979) ("where the Board differs with the administrative law judge without clearly explaining its reasons for disagreement, the Board's finding will be vulnerable' on review.").

80. Alabama Ass'n of Ins. Agents, 533 F.2d at 246. In contrast to review of Board orders, judicial review of Board regulations is made under the arbitrary-and-capricious standard for informal rulemaking. The Board's regulations are issued under informal nulemaking procedures because 12 U.S.C. $81843(\mathrm{c})(8)$, the statute authorizing the Board's rulemaking power in applying the exemption, does not require that regulations be made on the record. See Association of Bank Travel Bureaus, Inc. v. Board of Governors of Fed. Reserve Sys., 568 F.2d 549, 552 (7th Cir. 1978). The standard of review for informal rulemaking is provided for under the Administrative Procedure Act, 5 U.S.C. 8 706(2)(A) (1976).

81. See National Courier, 516 F.2d at 1236. In reviewing Board regulations under the arbitrary-and-capricious standard, the proper definition of the term "closely related" is a question of law, to be determined by the court. Id. at 1235-36. The same primciple applies in reviewing orders under the substantial evidence standard. For example, in interpreting a statute providing for limited review of findings of fact by the National Labor Relations Board, the court noted that disputes relating to the meaning of the statutory term present questions of law not governed by the statute. NLRB v. Marcus Trucking Co., 286 F.2d 583, 590 (2d Cir. 1961); see also NLRB v. Brown, 380 U.S. 278, 290 (1965) ("courts are not obliged to stand aside and rubber-stamp their affirmance of administrative decisions that they deem inconsistent with a statutory mandate").

82. 450 U.S. $46,73-74$ (1980). 
lated test great deference. ${ }^{83}$ The Court noted that the Board's expertise in the technical field of banking exceeds that of the courts, and decided that the Board is better able to interpret its statute. ${ }^{84}$ The Court indicated that it would defer to the Board's decisions unless they were unreasonable or clearly incorrect. ${ }^{85}$ Under this test, a reviewing court has bittle power to intervene to alter the standards under which the Board applies the exemption. Because the Senate Managers supported liberalization of the exemption by granting more flexibility to the Board, ${ }^{86}$ the Board's flexible standard is not an unreasonable interpretation of congressional intent.

Strong practical considerations support the Court's view that the Board's interpretation of the statute is entitled to deference. First, consider the consequences of a court decision implementing the House Managers' interpretation of section $4(\mathrm{c})(8) .{ }^{87}$ The problem with this

83. See id at 56.

84. The Court cited the following comments of Justice Rutledge:

Not only because Congress has committed the system's operation to their hands, but also because the system itself is a highly specialized and technical one, requiring expert and coordinated management in all its phases, I think their judgment shonld be conclusive upon any matter which, like this one, is open to reasonable difference of opinion. Their specialized experience gives them an advantage judges cannot possibly bave, not only in dealing with the problems raised for their discretion by the system's working, but also in ascertaining the meaning Congress had in mind in prescribing the standards by which they should administer it. Accordingly their judgment in such matters should be overturned only where there is no reasonable basis to sustain it or where they exercise it in a manner which clearly exceeds their statutory authority.

Id. at 56 n.21.

85. Id at 56-58 \& nn.20-23. Courts often accept administrative interpretations of statutes when statutory terms are not defined by Congress. In NLRB v. Hearst Publications, Inc., the Court approved the agency's interpretation of the term "employee" after determining that the agency's definition was consistent with the statutory purpose and that Congress had not attempted to define the term. See 322 U.S. 111 (1944).

An important difference exists between section $4(c)(8)$ and the statute in Hearst. The Hearst Court found a clear statement of congressional policy against which it could measure the agency's interpretation for consistency. See id. at 126-29. The division of opinion among the Congressmen who enacted section $4(c)(8)$ makes it impossible to say whether the Board's imterpretation of the statutory term "closely related" is consistent with congressional policy. Judicial deference in this case gives rise to problems of lack of accountability and uncontrolled administrative discretion. See infra Part IV.

86. See supra note 45.

87. The House Managers attempted to retain the standards applied under the 1956 Act. See supra note 46 for discussion of the standards under the 1956 Act.

As an alternative to attempting to apply the House's interpretation of the statute, a court could declare the legislative history of section $4(c)(8)$ to be hopelessly ambiguous and rely on the technique of literal interpretation to construe the statute. The current trend in statutory interpretation appears to be toward "a literalist reading of statutory terms as a surrogate for actual legislative intent" when the legislative history is silent or ambiguous. Note, Intent, Clear Statements, and the Common Law: Statutory Interpretation in the Supreme Court, 95 HARV. L. REV. 892, 894 \& n.21 (1982).

The Board approved the Administrative Law Judge's application of the technique of literal interpretation in the Transamerica order, the resnlting interpretation of the exemption provision 
judicial intervention is that it would not make the application of section 4(c)(8) more consistent with legislative intent. The revised standard would be consistent with the views of the House Managers, but would directly conflict with those of the Senate Managers who supported a flexible test and intended the 1970 Amendments to enact such a test. ${ }^{88}$ No single standard, whether imposed by a court or the Board, can give effect to the divergent views expressed in the legislative history of section 4(c)(8). Intervention by the courts to impose new standards on the Board is likely to make inatters worse. As the Court noted, the Board's expertise in the field of banking, built through years of regulation, outweighs that of the courts. ${ }^{89}$ The Board rehes on this expertise to establish workable standards in the face of Congress' inability to agree on the proper standards to govern the application of section 4 (c) $(8) .90 \mathrm{Be}-$ cause courts lack practical experience in regulating banks, they are in a poor position to judge whether another standard will prove to be superior. Congress has only a limited amount of time to devote to the numerous policy questions it faces. In cases of great internal division, practicality may dictate that the process of standard setting be left, at least for a time, to an agency. ${ }^{91}$ Professor Davis notes that this flexible tool allows building of standards through an agency's application of a statute. ${ }^{92}$ By applying standards and measuring results, the agency is able to establish rational guidelines under the statute. In hight of these

was that nonbanking activities must be a reasonably required part of the banking business. See supra note 46.

88. See supra note 45.

89. Expertise has been used to justify delegating discretion to the agency by enactment of statutes with imprecise standards. For example, in Fahey v. Mallonee, the Court noted that because banking is one of the longest regulated and inost closely supervised of public callings, regulators have a great deal of expertise. 332 U.S. 245, 250 (1947). This factor may allow a discretion to make regulations in areas of expertise that might not be upheld in unfamiliar fields. Id.

90. The Supreme Court deferred to the Board's standards because the Board's expertise can "enlighten and rationalize the search for the meaning and intent of Congress." Board of Governors v. Investment Co. Inst, 450 U.S. at 68 (quoting Investment Co. Inst. v. Camp, 401 U.S. 617, 628 (1971)(1). In fact, the Board's expertise cannot aid it in understanding the intent of Congress because in this case the Houses were in direct conflict over the purpose of the amended provision, and no single congressional intent exists. Nevertheless, the Board's expertise gives it an advantage over courts in attempting to develop workable standards in the absence of a legislative purpose.

91. See 1 K. Davis, Admanistrattve LAw Treatise $155-56$ (1978). In Yakus v. United States, the Court noted that the Constitution does not require Congress to find every fact and make every determination on its OWn as a prerequisite to legislative action. 321 U.S. 414, 424 (1944). Instead, so long as it sufficiently marks the limits of the administrator's field of action, Congress has fulfilled its duty. See id at 425 .

92. Davis suggests that if Congress fails to prescribe the required standards for discretionary action in a statute, administrators should be allowed to satisfy the requirement by prescribing them within a reasonable time. K. DAvis, supra note 91 , at 211. Standards adopted through administrative rulemaking are just as effective in confining and guiding the discretionary determination as standards stated in a statute. Id. 
practical considerations, the best course of action for the courts is to defer to the standards set by the Board in the application of section $4(c)(8)$.

The conclusion that courts are justified in refusing to impose new standards to govern the application of section 4(c)(8) does not suggest that the Board's standards should not be scrutinized and perhaps altered. The Board's flexible standards deviate froin the standards envisioned by the House Managers. The Board made an important policy decision in adoptimg its flexible standard, and the effects on the public and nonbank competitors could be serious if the policy choice proves unwise.93 A fundamental notion of our democratic system is that important policy choices should be made by law makers accountable to the electorate, and the Board is subject to no such accountability. ${ }^{94}$

Congress should review the standards established by the Board in order to restore accountability to the electorate in the application of section 4(c)(8). Congress is responsible for making law, and the onus of legitimizing, altering, or rejecting the Board's flexible standards must fall on Congress. The courts should imtervene, not by setting standards, but by encouraging Congress to fulfill this duty. By revising the delegation doctrine, the courts would encourage Congress to review the Board's standards.

\section{The Duty of Congress to Review the BoARD's FleXible APPROACH IN APPLYING SECTION 4(c)(8)}

According to Judge Skelly Wright, "[w] hen Congress is too divided or uncertain to articulate policy, it is no doubt easier to pass an organic statute with some vague language about the 'public imterest' which tells the agency, in effect, to get the job done." 95 Congress' approach to the revision of section 4(c)(8) in the 1970 Amendments supports this observation. ${ }^{96}$ Although section $4(\mathrm{c})(8)$ directs the Board to examine the relationship between banking and nonbanking activities, the split in Congress over the meaning of "closely related" gives the

93. See supra Part II.

94. See infra text accompanying notes $99-101$.

95. Wright, Bejond Discretionary Justice (Book Review), 81 YALE L.J. 575, 584-85 (1972).

96. In drafting section $4(c)(8)$, Congress faced the difficult policy choice of whether to liberalize the closely-related exemption, risking concentrations in the financial sector and harm to nonbank competitors, in order to gain possible public benefits of convenience, efficiency and more competitive banks. In the end, Congress remained deadlocked on the issue, and the Board made the policy decision. The Amendments enacted the public benefits test, but this restriction amounts to little more than what Judge Wright calls "vague language about the 'public interest.'" See supra Part II for criticism of the public benefits test. 
Board complete discretion to define the required relationship broadly or narrowly. ${ }^{97}$

The Supreme Court defers to the Board's judgment in applying the closely related provision because of the Board's expertise.98 Although the Court's position is justified, Judge Wright notes a problem with this process: "An argument for letting the experts decide when the people's representatives are uncertain or cannot agree is an argument for paternalism and against democracy." 99 He notes that in some cases, the agency will formulate standards and establish guidelines for its actions, ${ }^{100}$ as the Federal Reserve Board has done in interpreting section 4(c)(8). Judge Wright cautions that in such cases, standards and pohicy are set at the expense of democratic decisionmaking. ${ }^{101}$ Professor Davis agrees at least that agencies "should not have unguided and uncontrolled discretionary power to govern as they see fit."102 Yet the Supreme Court's rationale for adopting a policy of deference to standards set by the Board is persuasive. The question presented, then, is how to preserve the benefits of standard-setting by the Board without unduly sacrificing democratic processes.

Professor Davis answers this question by proposing a recast delegation doctrime under which flexibility and accountability can be maintained through a two step process: courts should require administrators to establish rules and standards to guide their discretionary determinations, and Congress should supervise major policymaking by agen-

97. Judge Wright called for reevaluation of the delegation doctrine in extreme cases in which statutes governing agency discretion contain only vague language about the public interest. See Wright, supra note 95 , at 584-85.

The delegation doctrine (or nondelegation doctrine) requires a court to strike down statutes that attempt to confer powers that Congress cannot delegate. See Panama Refining Co. v. Ryan, 293 U.S 388, 430 (1935) ("in every case in which the question has been raised, the Court has recognized that there are limits of delegation which there is no constitutional authority to transcend"). The doctrine is grounded on the principle that the separation of powers established by the Constitution places limits on the exercise of legislative power by non-elected officials such as administrators. See Industrial Uvion Dep't v. American Petroleum Inst., 448 U.S. 607, 672-75 (1980)(Rehnquist, J., concurring).

The Supreme Court has invoked the doctrine to strike down delegations of power to governmental organizations in only two cases: A. L. A. Schechter Poultry Corp. v. United States, 295 U.S. 495 (1935), and Panama Refining Co. v. Ryan, 293 U.S. 388 (1935). 1 K. DAvis, ADMINISTRATIVE LAw TREATISE 151 (1978). The doctrine has fallen into disuse and may no longer be viable. See id. at 149-52, but see infra note 109.

Section 4(c)(8) appears to satisfy the requirements of the delegation doctrine as traditionally formulated. See infra note 109. Nevertheless, the statute presents a strong case for application of a recast delegation doctrine based on the premise that if Congress delegates standard setting to agencies, it should review the standards established. See infra text accompanying notes 105-108.

98. See supra text accompanying notes 82-86.

99. Wright, supra note 95 , at 585 .

100. Id at 585-86.

101. Id at 586.

102. See 1 K. Davis, Administrative LAw Treatise 206 (1978). 
cies. ${ }^{103}$ By reviewing standards set by agencies, Congress can either accept responsibility for the agency's decisions by approving them or reject the standards as unjustified. 104

At present, Congress has little incentive to undertake such a review on its own initiative. By leaving the decisionmaking process solely to the Board, Congress is able to avoid responsibility for any adverse consequences that may result from the Board's policies. By altering the delegation doctrine to provide incentives for congressional review, ${ }^{105}$ the benefits of standard-setting by agencies can be achieved without sacrificing accountability. Congress would be allowed to delegate the process of standard-setting, but courts would be charged with the responsibility of taking action to encourage legislative review of the standards established if Congress fails to undertake review on its own initiative. 106

The current conditions surrounding the application of section 4(c)(8) present a strong case for application of a remodeled delegation doctrine. The division among the legislators granted the Board complete discretion to choose either rigorous or flexible standards in apply-

103. Id.

104. The essence of the notion that policymaking should be supervised by those accountable to the electorate was expressed by Senator Paul Douglas:

[T] he American people have never been willing to confide their individual or collective destinies to civil servants over whom they have little control. They distrust and dislike a self-perpetuating bureaucracy, because they believe that ultimately it will not reflect the best interest of the people. They therefore turn to their elected representatives to protect their legitimate interests in their relationships with public administrators. The people feel that this is part of a legislator's duties, as indeed it is, and if a legislator washes his hands of any such responsibility, he may expect very soon to be retired to private life.

P. DOUglas, Ethics IN Government 87-88 (1952).

105. The delegation doctrine as traditionally formulated was intended to encourage Congress to include standards im statutes enacted. Justice Rehnquist views the doctrine as having three purposes: (1) to ensure that Congress makes important policy choices, (2) to ensure that agencies receiving authority from Congress are guided by intelligible standards in the exercise of their discretion, and (3) to provide standards against which courts may check agency actions for abuse of authority. See Industrial Union Dep't v. American Petroleum Inst., 448 U.S. 607, $685-86$ (1980) (Rehnquist, J., concurring). This formulation emphasizes Congress' duty to provide standards at the time a statute is enacted in order to guide agencies and reviewing courts.

Professor Davis argues that this emphasis on standard setting caused the doctrine to fall into disuse. See 1 K. Davis, Administrative LAw Treatise 150-57 (1978). Rigorous application of the doctrine would limit agency flexibility to arrive at workable standards through application of a statute.

106. The more drastic means by which a court could encourage legislative review is to refuse to allow the Board to apply the exemption provision until Congress acts. An alternative technique is to refuse to review Board orders or regulations applying the statute for anything more than compliance with procedural requirements until Congress clarifies the purpose of section $4(\mathrm{c})(8)$. Judicial review of agency actions for compliance with their enabling statutes is necessary to legitimize the agencies' authority, and therefore this tactic could be equally effective in prompting congressional review. 
ing the provision. The Board opted for flexible standards that broadened the exemption, and Congress nnay now review the results of that policy decision. In addition, Congress and the courts should be especially sensitive to the problen of lack of accountability, because the Board is closely tied to the interests of banks. Its members interact constantly with meinbers of the banking industry, and nonbank coinpetitors may justifiably wonder whether the Federal Reserve Board is truly an impartial policymaker in weighing their interests against those of the banks. ${ }^{107}$ The Board was a inajor force behind the move to broaden and liberalize the closely-related provision in the 1970 Amendments. ${ }^{108}$ It is not surprising that the Board used the division in legislative intent to proceed with liberalization on its own. Despite these concerns, courts have no tool other than the delegation doctrine with which to encourage Congress to undertake review of the Board's standards. ${ }^{109}$ Modifying the doctrine to encourage or require Congressional review of standard-setting by agencies would give courts the

107. See Professor Cramton notes that programs and policy goals within an agency may make impartial adjudication difficult. Cramton, supra note 68, at 589.

108. Board Chairmen Martin and Burns, as well as various Nixon administration officials, "strougly and repeatedly urged that a new, broader test be adopted." House MANAGERs' REPORT, supra note 16, at 19-20, reprinted in 1970 U.S. CODE CONG. \& AD. News at 5570-71. Their position was rejected by the House Managers. See id. at 21, reprinted in 1970 U.S. CODE CoNo. \& AD. NEws at 5572.

109. Professor Davis argues that the traditional delegation doctrine has been a complete failure and is no longer viable. See $1 \mathrm{~K}$. Davis, Admmistrattve Law Treatise 150-52 (1978). However, Justice Rehnquist considered the doctrine to be applicable in the Industrial Union Dep't case. See 448 U.S. at 671 (Rehnquist, J., concurring). Nevertheless, the delegation to the Board under section $4(c)(8)$ appears to be safe from attack under the traditional delegation doctrine as formulated by Justice Rehnquist.

Justice Rehnquist first attacked the statute before him in Inchustrial Union Dept. because it gave the administrator no indication where to set standards for exposure to hazardous substances. See id at 675. In addition, he found nothing in the statute's legislative history that limited the administrator's discretion. See id. at 676-82. He argued that the statute should be struck down under the delegation doctrine because the administrator had no intelligible principle to guide the exercise of his discretion, and courts had no standards against which to measure the administrator's actions for lawfulness. See id. at 685-86.

In contrast, the Board is at least limited in its attempts to liberalize the exemption provision by the Senators' requirement that a functional relationship exist between the proposed activity and banking activities. See supra note 45. Thus the Board is not operating with a complete lack of guidance in the exercise of its discretion. Courts have used this requirement to limit the Board's power, as is demonstrated by the limitations on chaining together of close relationships imposed by the National Courier court. See supra text accompanying notes 30-34.

Finally, Rehnquist noted that the Court looks to sources other than legislative history to breathe life into otherwise vague delegations of legislative power. See Industrial Union Dep't, 448 U.S. at 682 (Rehnquist, J., concurring). The court relied on the Board's expertise to support the delegation to the Board of discretion under section 4 (c)(8). See supra notes $89-90$ and accompanying text. Expertise residing in the agency did not aid Justice Rehnquist because the policy question Congress delegated was whether the statistical possibility of deaths should ever be disregarded in light of the economic costs of preventing those deaths. See Industrial Union Dep't, 448 U.S. 672 
power to intervene to achieve accountability, to legitimize the exercise of administrative discretion, and erase clear uncertainty. ${ }^{10}$ Under current practices, accountability is maintained only if Congress undertakes review on its own initiative.

\section{CONCLUSION}

With the adoption of a flexible and expansive interpretation of section 4(c)(8), bank holding companies are able to expand their range of nonbanking activities. The legislative history indicates that Congress did not clearly intend that bank holding companies expand their activities, and analysis of the statute indicates that the public benefits test does not adequately guard against potential dangers of liberalization.

Adverse competitive effects could be restricted by enforcing a strict closely-related test or by altering the current statutory scheme to reflect differences in holding company entry into regulated as opposed to coinpetitive industries. Perhaps the anticoinpetitive risks are sufficiently remote that a flexible test is justified in all situations. In any case, these options require serious study by Congress, the body responsible for making important policy decisions. Congress should review the standards and policies evident in the Board's Citicorp Order and legitimize or alter them on the basis of its findings.

Although the delegation doctrime as traditionally formulated does not encourage Congress to undertake a review of standards established

(Rehnquist, J., concurring). Because this was a question of social values, delegation could not be justified on the basis of the agency's technical expertise. See id

Although section 4(c)(8) might survive Rehnquist's test for permissible delegation of standard setting in the first instance to an agency, the standards established by the Board have substantial public policy overtones: they affect the viability of nonbank competitors' businesses and could result in concentrations of power in the financial industry. If the delegation doctrine were recast as suggested in this note, Congress could realize the benefit of agency expertise because delegation of standard setting would be permissible. However, once the standards are set and the public policy implications are known, courts would apply the doctrine to encourage congressional review in order to establish Congress' accountability for the policy decisions made by the agency. See supra text accompanying note 105 .

110. Although nonbank competitors are threatened by the current Board policy, Citicorp and other bank holding companies could be big losers should Congress decide to intervene in the future for some reason. Citicorp noted in the hearings that development of expanded data services capabilities by bank holding companies will entail great capital investments, and expressed concern that decisions to inake such investments can not be made prudently if the propriety of bank holding company eugagenent in data services activities is subject to attack in the future. 1981 House Hearings, supra ncte 57, at 319 (statement of Patrick Mulhern). Therefore, Citicorp called for a clear statement of policy regarding bank holding company expansion of data services activities. Id. The Citicorp order grants clear approval of the proposed expansion of services, but Congress conciuded in 1956 and 1970 that nonbanking activities engaged in by holding coinpanies were excessive, and it could do so again. See supra note 6 . By reviewing the Board's standards, Congress could inake clear its approval of the Board's policies. 
by agencies, the revisions in the doctrine proposed by Professor Davis would achieve this result. Under the revised delegation doctrine, the standard setting process delegated to the Board in the first instance is permissible, but courts could subsequently refuse to uphold the statute until Congress reviewed the Board's standards. Without such a revised doctrine, accountability can be achieved only if Congress recognizes its duty and reviews agency standards on its own initiative.

Christopher W. Loeb 